\title{
Factors Influencing Generation Y African Americans In Their Choice For College Education: An Empirical Case Study Of Fort Valley State University Students
}

Prof. Samuel K. Gyapong, PhD, Fort Valley State University, USA

Prof. Thomas Smith, MBA CPA, Fort Valley State University, USA

\begin{abstract}
In an effort to assist a newly appointed Public Relations Officer to determine the most effective way to promote the institution to college-bound Generation $Y$ African-Americans we offered to conduct a survey research of our current students. The results were very revealing and have been used successfully to increase enrollment to historically high rates in the past two years. This paper is an attempt to share the research methodology and the revealing results. It recounts the research objectives, methodology including data collection and analysis and the results.
\end{abstract}

Keywords: Generation Y; African American Students

\section{INTRODUCTION}

ne dimension for segmenting the United State's market has been by generations. Several Marketing Management textbook authors identify different generations beginning with those born before the Second World War, and ending with those being born at the turn of the $21^{\text {st }}$ century.

Hawkins, Mothersbough and Best (2007) define Generation or Age Cohorts as " a group of persons who have experienced a common social, political, historical and economic environment" The authors use the definition to identify five different generations ; the Pre-Depression Generation, Depression Generation, Baby Boom Generation, Generation X, and Generation Y. The periods of birth of all the generations, the current age range and the size of each generation in the U. S. population are compiled in Table 1. In addition to the five generations is the current generation identified as Millennial Generation; those being born now beginning from five years before the turn of the century. The leading edge of that generation is currently in grade school at best.

In the seventh edition of their book ' Understanding Business' William Nickels, James and Susan McHugh (2005) also identify three generations as "Baby Boomers (born between 1946 and 1964); Generation X (born between1965 and 1980); and Generation Y (born between 1981 and 1994).

Table 1: Generational Cohorts in the U.S. Population in2010

\begin{tabular}{|l|l|c|c|c|}
\hline & \multicolumn{1}{|c|}{ Generation } & Period of Birth & Age Group & Size in US Millions \\
\hline 1 & Pre-Depression & Before 1930 & $80-100+$ & 18 \\
\hline 2 & Depression & $1930-1945$ & $65-79$ & 32 \\
\hline 3 & Baby Boom & $1946-1964$ & $46-64$ & 80 \\
\hline 4 & Generation X & $1965-1976$ & $34-45$ & 45 \\
\hline 5 & Generation Y & $1977-1994$ & $15-33$ & 71 \\
\hline 6 & Millennial Gen. & $1995-$ Present & $0-14$ & unknown \\
\hline
\end{tabular}

Note: Compiled from Hawkins, Del J., David Mothersbaugh and Roger J. Best,

Consumer Behavior, Building Marketing Strategy, 10th Edition, McGraw-Hill Irwin, 2007 
The characteristics of these generations have been described in several Marketing books. Nickels, McHugh and McHugh (2005) describe Generation Y cohorts as "inpatient, skeptical, blunt and expressive, image-driven and inexperienced" On the positive side they describe them as "adaptable, tech savvy, able to grasp new concepts, practiced at multitasking, efficient and tolerant"

Hawkins and Co (2007).describe them as "the first generation to grow up with ---computers in the home and schools and with the Internet" It is for this reason that they are often referred to as "Dot Com" generation; the familiar end to internet addresses. All kinds of adjectives are used to describe them. However, the description that is of interest to University and College administrators is that "This generation as a whole, is expected to be the highest educated generation to date with incomes that should follow" For that reason the Y-Generation is the one that has become of interest to administrators of institutions of higher learning such as Colleges and Universities in the United States. The leading edge of this generation is either currently in college or in the workforce while the trailing edge is in high school and soon to enter Universities or Colleges. Management of Universities and Colleges are making all efforts to attract these potential candidates for higher education

The justification for choosing African Americans of the Y Generation for this study springs from a statement by Paul Peter and Jerry Olson (1996) in discussion of subcultures and social class in their Consumer Behavior textbook. They postulate that "Consumers in different age categories (such as the 30 to 50 boomer group versus 50 to 65) are likely to have somewhat different values, cultural meanings, and behavior patterns. Partly, this is because people in these age categories grew up in different decades with different cultural experiences. However, it should be recognized that these broad sub-cultural segments can be quite diverse. Therefore marketers may have to use other variable to identify narrower and more precise segments. For example, the age categories could be further broken down into ethnic, geographic, religious or community subgroups". The African American segment of Generation Y was chosen for this study because Fort Valley State University, as one of the Historically Black Colleges and Universities (HBCU) in the United States, draw the bulk of their student population from among African American families, mostly in the South of the United States.

In the United States Federal and State government funding for higher education is based, to a large extent, on institutional enrollment. For that reason, universities use all kinds of marketing practices to attract as many qualified college-bound high school graduates and non-traditional candidates as they can accommodate. Fort Valley State University is no exception. There is ample evidence in the media that most of these expensive marketing efforts really do not yield the volume of applications for admissions to justify the expense According to Hawkins Mothersbaugh, \& Best, (2007) "Traditional mass-marketing approaches that were so successful with older generations often do not work well with younger consumers including those in Generation Y. Companies must continually push the creative envelope with respect to media and promotional themes to capture this audience." A relatively small institution such as Fort Valley State University can not afford to waste its meager advertising budget on popular but in-effective marketing strategies.

In the year 2006 when the US economy began to show signs of weakening and funds for higher education (and indeed all levels of education) from both Federal and State appropriations became scarce Fort Valley State University hired a new president. The president made enrollment increase the major objective of his strategic initiatives. In the first year of this President's administration he appointed a marketing director to develop and implement a strategy to increase enrollment which had been dropping in the years before his appointment. As part of her strategy for promoting to the traditional target group the marketing director determined that it might be very helpful if a study could be conducted to determine the most cost effective way of promoting to the target group with limited financial resources. She believed that any marketing efforts would be more productive if they were guided by scientifically generated information about the media habits of the target generation and how to promote to them. We accepted the challenge to conduct a scientific study using a Marketing Research class to determine how the target market group makes their University choices for their college education

\section{PROBLEM STATEMENT}

The primary purpose of this research was to generate reliable information about how to promote to this target group. Although the new director and her staff were working hard to increase student enrollment, they needed 
reliable information on effective ways of communicating to the target market and other stake holders. There was no information on the media habits of the target generation and what messages influence them the most when considering their choice of institution for college education. Therefore, the director needed scientifically generated information based on primary data that could form the basis for developing promotional campaigns with a limited budget. Since no provision was made in her budget to pay for research, using a campus research class to conduct an exploratory study using the current student body of the university as a representative group of the population of interest was quite convenient.

\section{RESEARCH OBJECTIVES}

The objectives of this research were threefold. First it was necessary to determine the most effective media to reach the primary target market (Generation Y African- Americans). This subgroup of Americans who forms the principal target for recruitment efforts of Historically Black Colleges and Universities (HBCUs) have not been studied in terms of their media habits; whether they differ or are similar to the media habits of the mainstream Y generation. The study was to make that determination. The second objective was to determine who or what influence the target market in their decision making process, especially as it relates to choice of an institution for their college education. That information would enable the director to determine who or what to include in promotional efforts. The third objective was to determine the types of message or information that influence Generation Y African Americans in their decision about college. The combination of the right media, the right influencers and the right messages, it was hoped, will result in more effective promotion to this target market group to accomplish the enrollment increase objective of the institutional leadership.

\section{RESEARCH METHODOLOGY}

Primary data was used for this research, and was collected using intercept survey method. This method was chosen because, unlike other data gathering methods, the survey intercept method provides a good response rate. It was also the most cost effective and less time-consuming considering the population of interest. The population of interest, the current Fort Valley State University students, could be reached easily on any day, either in classes, in the dining hall during meal times, in the library or at the stadium on game days or at any official gatherings.

The Population of Interest was fall 2007 Fort Valley State University Students. The sampling method used was a combination of Cluster (by classrooms) and Quota (by class standing). The reason for using FVSU students was that, demographically, they represent the Generation Y population of the US, and have already experienced what prospective students will undergo in their search for a college institution. Thus it can be said that a convenience sampling method was used. The sample size chosen was 300 students, which was approximately $12 \%$ of the student population of the university in the semester that the study was conducted.

A questionnaire was designed by the research team for this primary data collection. This was an exploratory research and no standard data gathering instrument was available to use. Prior to using the instrument, it was tested on students in the class and the data collected was compiled and trial analysis was conducted to determine if the objectives could be achieved. After the first trial, a few additional questions were added to the original questionnaire and tested again. After the team had made sure that data collected with the final instrument would be analyzable and would yield the information sought, the questionnaire was finalized and coded for spreadsheet analysis of the data.

On the day for data collection members of the research team administered the questionnaire to students during classes. Classes were selected randomly from the list of classes offered that semester; allowing for proportional representation of all undergraduate class standings. Research teams of two each were assigned to different classes at a given time to administer the questionnaire to students. After seeking the permission of the instructor at the beginning of the class, questionnaires ware distributed to the students. The questionnaire took between ten and fifteen minutes to complete. The research team collected the response sheets and thanked the instructor. Although a sample size of three hundred was to be used for the study a total of about three hundred and sixty response sheets were collected. 


\section{Data Tabulation and Analysis}

Collected data were edited to screen out incomplete and/or poorly completed response sheets, and three hundred satisfactory response sheets were coded and numbered in preparation for data compilation on spreadsheet using Microsoft Excel. The data was compiled by students in the marketing research class after being introduced to the

Excel spreadsheet. This portion of the research took over three weeks with pairs of students taking turns to compile all the data on one spreadsheet. Before analysis of the data, the data entry was checked item by item, sheet by sheet, data by data, to ensure that each piece of data was entered correctly.

After checking the compilation of the data on EXCEL spreadsheet and correcting a few minor entry errors, frequency of responses to each question were generated. These frequencies were compiled, analyzed and presented in various forms. Frequency of response analysis sounds simplistic and unsophisticated but the results were very revealing.

\section{Research Results}

The first objective was to determine the most effective media to reach this demographic group of Generation Y African Americans who are the current target population of interest to HBCUs. The first evaluative question asked was which media they used to search for information about college. The results show that $95 \%$ of the respondents chose the Internet as the preferred medium for searching for information about college. T.V. was a distant second with $2 \%$ of the respondents choosing it as their preferred medium. Radio, Billboards and Magazines came in third with $1 \%$ t each. No one chose newspapers as a source of information. These results are presented in Table 2.and Figure 1 below.

\section{Media Choice for College Information}

Table 2: Media Choice for College Search

\begin{tabular}{|c|c|c|c|}
\hline Rank & Media & Responses & $\begin{array}{c}\text { \% of } \\
\text { Responses }\end{array}$ \\
\hline 1 & Internet & 285 & $95 \%$ \\
\hline 2 & TV & 6 & 2 \\
\hline 3 & Radio & 3 & 1 \\
\hline 4 & Magazines & 3 & 1 \\
\hline 5 & Billboards & 3 & 1 \\
\hline 6 & Newspapers & 0 & 0 \\
\hline
\end{tabular}

Figure1:Media Choice for College Search

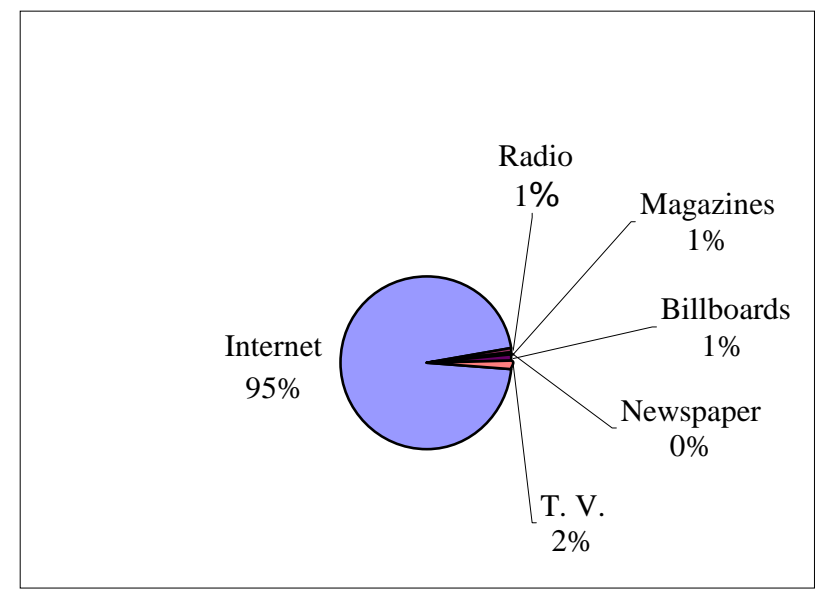

In an evaluative question about media choice respondents were asked what media they used to find information about Fort Valley State University (FVSU). The Internet was chosen by $89 \%$ of the respondents. T.V. was again a distant second, followed by radio, billboards, and magazines in the same order.

To enquire further into their media habits the respondents were asked about which Internet search engine they use. $47 \%$ chose Goggle and $45 \%$ chose Yahoo. Those two were the most popular choices followed by Ask Jeeves with 3\%, MSN and Dogpile with 2\% each. See table 3. 
Table 3: Internet Search Engine of Choice

\begin{tabular}{|c|c|c|c|}
\hline Rank & Internet search Engine & Responses & \% of Sample \\
\hline 1 & Google & 142 & 47 \\
\hline 2 & Yahoo & 136 & 25 \\
\hline 3 & Ask Jeaves & 9 & 3 \\
\hline 4 & MSN & 7 & 2 \\
\hline 5 & Dogpile & 6 & 2 \\
\hline
\end{tabular}

The results also revealed that TV channels most popular among the population of interest are Black Entertainment Television (BET) and Entertainment and Sports Program Network (ESPN) as shown in Fig.2. Most students watch these programs in the evening and late nights. re The most popular magazines with this demographic group were Vibe, XXL, followed by Jet, Ebony, Essence, Source and King, in descending order

Table 4: Popular TV Programs

\begin{tabular}{|c|c|c|c|}
\hline Rank & Program & Responses & \% OF Resp. \\
\hline 1 & BET & 96 & $32 \%$ \\
\hline 2 & ESPN & 84 & 28 \\
\hline 3 & FOX & 31 & 10 \\
\hline 4 & MTV & 23 & 8 \\
\hline 5 & ABC & 12 & 4 \\
\hline 6 & CNN & 6 & 2 \\
\hline 7 & NBC & 3 & 1 \\
\hline 8 & Other & 45 & 15 \\
\hline
\end{tabular}

The second objective was to determine who or what the primary influencers of their college choice decisions were. The results show that family were the leading influencers followed by friends and Alumni and high school authorities. (Figure3). However, when asked what most influenced their choice of FVSU, 55\% chose programs, followed by cost and then families and friends. See fig. 4

Fig 3: Influences of College Choice

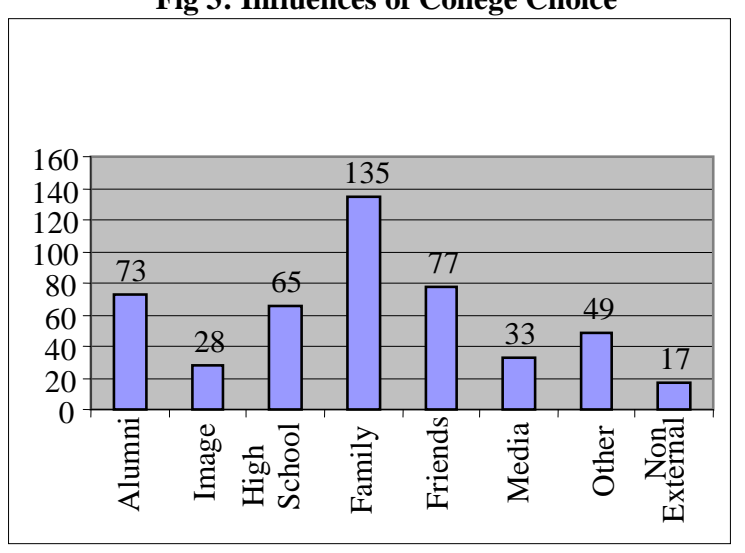

Fig 4: Factors Influencing Choice of FVSU

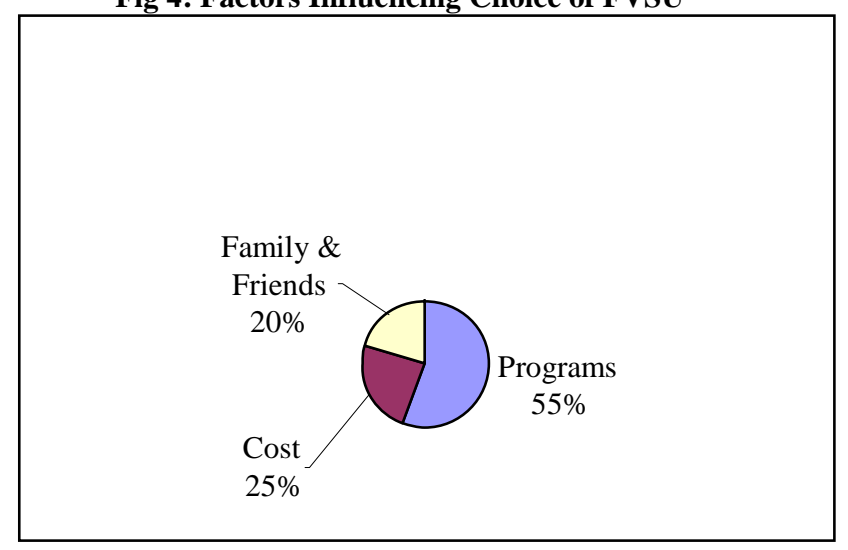

Objective three sought to determine what messages or information they search for and consider in their decision making about college. The results show that tuition was the most important information followed by location, curriculum, facilities, activities, and class size in that order as illustrated in Figure 5. Because the question allowed respondents to select as many as apply the results are comparative, not cumulative. 
Fig 5: Information on Institution essential to choice

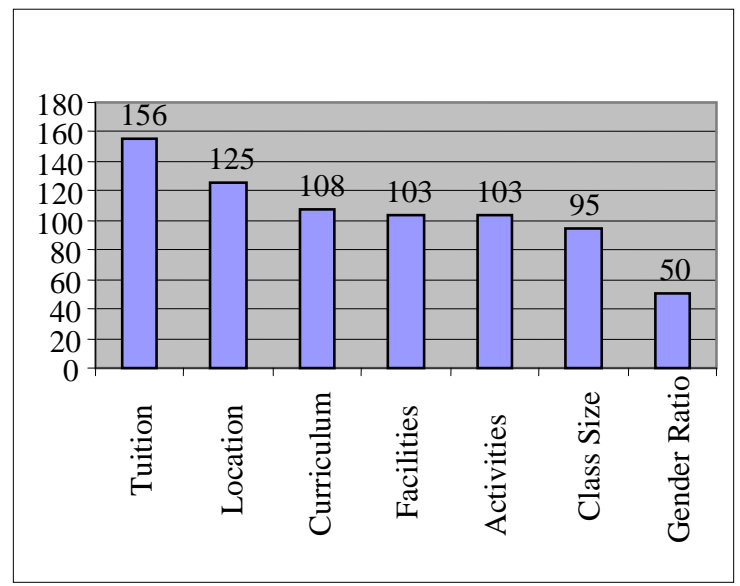

Fig 6: Age Distribution of Respondents

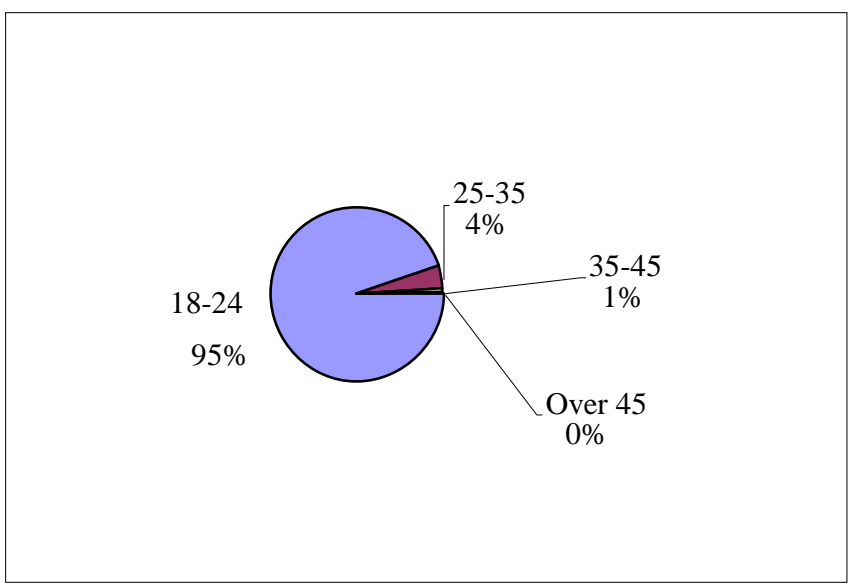

The research instrument was designed to collect some demographic data about our students. One piece of demographic information considered very useful was where our students come from. The results of the relevant classification question showed that $55 \%$ of the students come from Atlanta Metropolis compared to $37 \%$ from Central Georgia where fort Valley State University is situated. Only $4 \%$ come from out of State and $4 \%$ were international students. This is represented in Table 5 and Fig.7. In terms of racial mix the research showed that $94 \%$ of the students were African Americans, 1\% Hispanics, 2\% White and 3\% Other. This is shown in Figure 8 appendix B

Table 5; Students' Hometown

\begin{tabular}{|c|c|c|c|}
\hline Rank & Origin & Responses & \% Of Resp. \\
\hline 1 & Atlanta Metropolis & 165 & 55 \\
\hline 2 & Central Georgia & 111 & 37 \\
\hline 3 & Out-of-State & 13 & 4 \\
\hline 4 & Foreign & 11 & 4 \\
\hline
\end{tabular}

Fig 7: Hometown/Region of Respondents

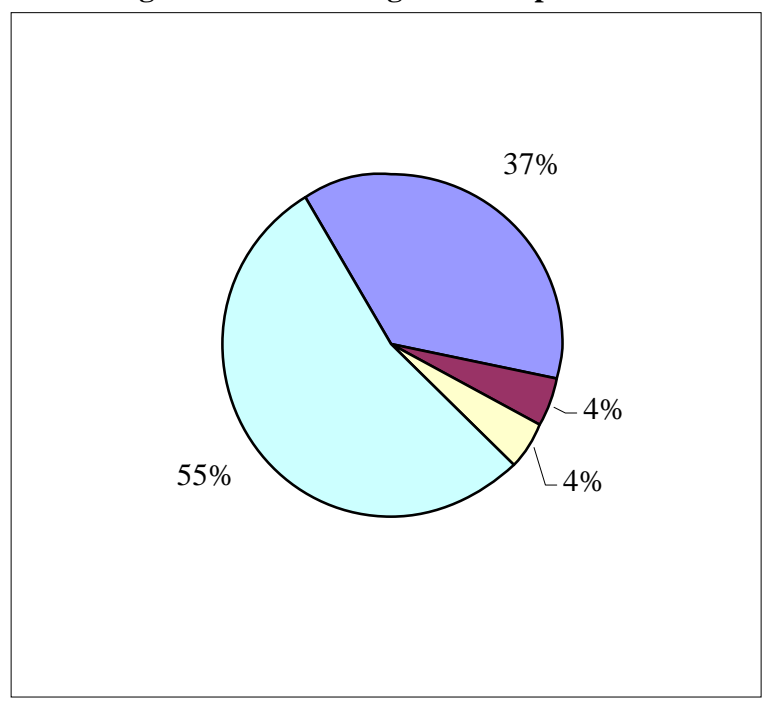

Fig 8: Racial Mix of Respondents

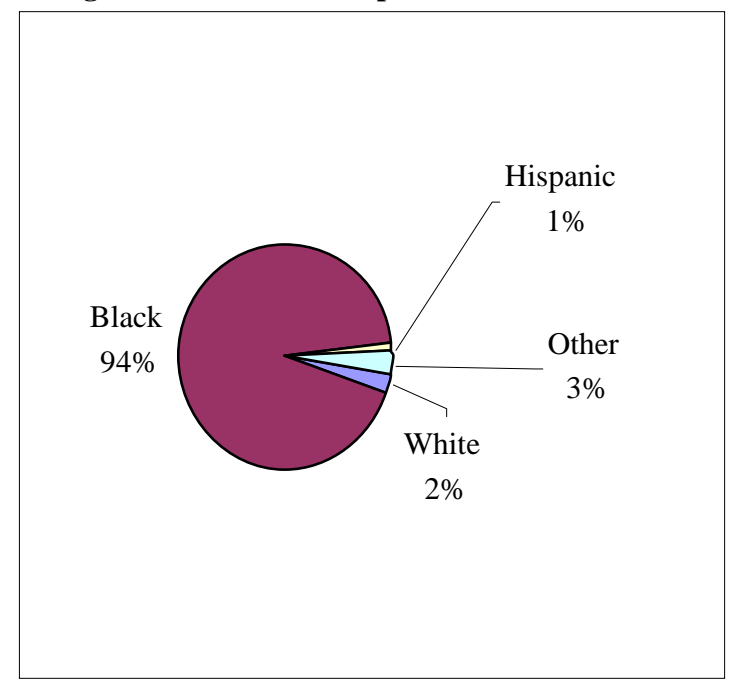




\section{RECOMMENDATIONS}

The following recommendations are made based on the research findings:

1. Institutions should concentrate their efforts on designing an attractive, user-friendly home page that provides prospects with information on Tuition, Programs, Location, facilities on campus, and student activities that draw students.

Following this recommendation the university hired an expert web page designer to design a more userfriendly web page for the institution.

2. The second recommendation is that if any university wants to use TV to promote the institution, the most popular channels are BET and ESPN. Since the largest percentage of FVSU student body come from the Atlanta area followed by the Central Georgia area, it is recommended that promotion on TV should be concentrated in these two areas. However, a Market Development strategy to attract students from nontraditional sources with high African American population, such as the Savanna area, is also recommended.

3. Popular magazines to advertise in are VIBE, and XXL However, since the institution's image is a concern, magazines must be chosen discretely if at all.

4. Since families are the major source of influence, activities that involve family members of the prospective students, such as the ever popular preview day, are also recommended

5. Since this was a pioneering research, it was recommended that the research be repeated within four to five years to confirm or dispute the findings

\section{CONCLUSION}

The results confirm that the $\mathrm{Y}$ generation is truly the Dot com generation who depend to a large extent on the internet to research college choice prospects. Most are influenced by family and friends and alumni, more so than High School councilors. The kind of information they look for includes Tuition, Location (mostly away from home as most FVSU students come from Atlanta area). Programs, Facilities, and Activities are also important to them.

\section{LIMITATIONS}

1. The results of this exploratory applied research may be truly representative of the geographic area where most of our prospective students come from. However, even though it is a research of the media habits of Generation Y African Americans, it cannot be generalized as being true for Generation Y African Americans in the entire nation until a nationwide survey is conducted.

2. The tail end of the generation $\mathrm{Y}$ cohorts is about to pass through college age and the leading edge of the millennial generation is going to be the population of interest soon. Whether they will differ considerably from the Y generation in their media consumption or not remains to be determined. It may be inaccurate to assume that both generations have this in common. It may be necessary to conduct a national survey on the internet for both the remaining Y generation still in the pipeline and the millennial generation getting ready to enter college soon.

\section{AUTHOR INFORMATION}

Samuel Gyapong is a Fulbright Scholar and Professor of Marketing at The Fort Valley State University in Fort Valley, Georgia where he has taught Marketing courses for the past eleven years. He currently teaches Quantitative Methods and Supply Chain Management. Prior to coming to Fort Valley Dr. Gyapong taught at Longwood University and Virginia State University both in Virginia for several years. He started his teaching career at Kentucky State University in 1986 after earning his PhD in Logistics and Transportation at The Pennsylvania State University in December 1985. Dr. Gyapong earned his BS degree in Aviation Maintenance Management in 1981 and MBA in Aviation Management in 1982 from Embry-Riddle Aeronautical University in Daytona Beach, Florida. His research interests are in Air Transportation, Logistics and Consumer Behavior. E-mail Address: gyapongs@fvsu.edu. 
Thomas Smith is a CPA and Assistant Professor of Accounting at Fort Valley State University in Fort Valley, Georgia. He currently serves as Interim head in the Department of Business and Economics. Mr. Smith has taught all levels of Accounting Courses during his twenty one year tenure. He has extensive corporate experience with three Fortune Five Hundred firms in the areas of Cost, Financial Analysis, and General Accounting. Mr. Smith earned his BS degree in 1970 from South Carolina State University in Orangeburg, South Carolina, and MBA in Finance in 1977 from Fairleigh Dickinson University in East Rutherford, New Jersey. E-mail Address: smitht@fvsu.edu.

\section{REFERENCES}

1. Assael, H. (1995), Consumer Behavior and Marketing Action $5^{\text {th }}$ Edition, Southwestern Publications

2. Babby, E. and Fred Halley (1994), Adventures in Social Research, Data Analysis Using SPSS, Thousand Oaks, California: Pine Forge Press.

3. Bagozzi, R. P., Zeyney Gurhan-Canly, and Joseph R. Priester (2002), The Social Psychology of Consumer Behavior, Buckingham, Philadelphia: Open University Press

4. Burns, A. C., and Ronald F. Bush (1995), Marketing Research, Englewood Cliffs, New Jersey: Prentice Hall.

5. $\quad$ Freed, N. (2008), Understanding Business Statistics $2^{\text {nd }}$ Edition, Portland, Oregon: Independent Publishing.

6. $\quad$ Galvan, J. L. (2006), Writing Literature Review, $3^{\text {rd }}$ Edition, California: Pyrczak Publishing

7. Greenbaum, T. L. (1998), The Handbook For Focus Group Research, $2^{\text {nd }}$ Edition, New Delhi: Sage Publication

8. $\quad$ Griffin, R W (2008) Management; $9^{\text {th }}$ Edition. Boston, New York, Hough fin Mifflin publishing

9. Hair Jr., J. F., Mary Wolfenburger, David J. Ortinau, Robert P. Bush (2008), Essentials of Marketing Research, New York, N. Y.: McGraw-Hill Irwin publishing

10. Hawkins, D. I., Roger J. Best, and Kenneth A. Coney (1998), Consumer Behavior, Building Marketing Strategy, $7^{\text {th }}$ Edition, USA: Irvin/McGraw-Hill.

11. Jarboe,G. R.(1999), The Marketing Research Project Manual, $4^{\text {th }}$ Edition, Cincinnati, Ohio: SouthWestern College Publishing.

12. Kortler, P., (1988), Marketing Management, Analysis, Planning, Implementation, and Control, $6^{\text {th }}$ Edition, Englewood Cliff, New Jersey: Prentice Hall.

13. McDaniel, C. and Roger Gates, (1999), Contemporary Marketing Research, $4^{\text {th }}$ Edition, Cincinnati, Ohio: South-Western College Publishing.

14. McDaniel C. and Roger Gates, (2006), Marketing Research Essentials, $5^{\text {th }}$ Edition, New Jersey: John Wiley and Sons publication.

15. Nickels, W. G., James M. McHugh, and Susan M. McHugh (2005), Understanding Business, $7^{\text {th }}$ Edition, McGraw Hill Irwin.

16. Patten, M. L. (2007), Understanding Research Methods, An Overview Of The Essentials, $6^{\text {th }}$ Edition, USA: Pyrczak Publishing.

17. Peter, J. P., and Jerry C. Olson (1994), Understanding Consumer Behavior, Burr Ridge, Illinois: Irwin.

18. Peter, P. J, \& James H. Donnelly jr., (2009), Marketing Management Knowledge and Skills, $9^{\text {th }}$ Edition, McGraw-Hill Irwin.

19. Peter, P. \& Jerry Olson (1996), Consumer Behavior and Marketing Strategy, $5^{\text {th }}$ Edition McGraw-Hill Irwin.

20. Pyrczak F., and Rondall R. Bruce (2007), Writing Empirical Research Reports, $6^{\text {th }}$ Edition, Glendale, California: Pyrczak Publishing. 